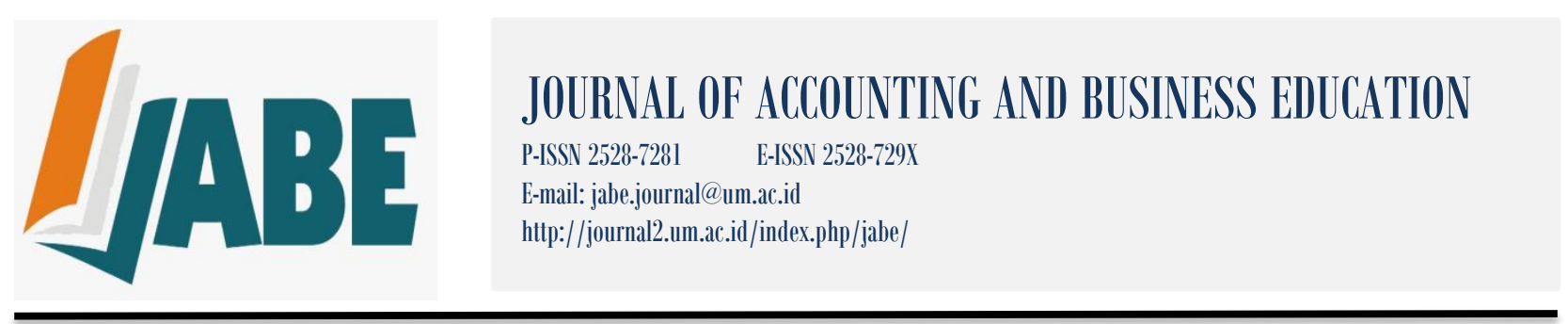

\title{
Le Grand Voyage: A Great Journey to Liberate Islamic Accounting Education from Utilitarianism and Secularism
}

\author{
Arista Fauzi Kartika Sari ${ }^{1}$ \\ Rahmawati $^{2}$ \\ Harun Al-Rasyid ${ }^{3}$ \\ ${ }^{1,2,3}$ Accounting Department, Islamic University of Malang, Indonesia \\ email: aristakartika@unisma.ac.id
}

DOI: http://dx.doi.org/10.26675/jabe.v4i1.6402

\begin{abstract}
The aim of this study is to release students of Islamic accounting course from secularism and capitalism. This research uses dialogic approach to raise the awareness of criticalmuslim students. The philosophical values of the French movie entitled "Le Grand Voyage" were taken as method of analysis. The reality of Islamic accounting students who are secularist and capitalist was then metaphorized into this film. The results of this study showed that the students could find not only material values, but also emotional values and spiritual values in accounting. There are several values that can be seen from the students' story telling: material value, altruism value, love value, and spiritual value. It is hoped that this article could give an overview to Islamic accounting educators to provide accounting course accompanied by Islamic substance of tawheed.
\end{abstract}

Keywords: Hijrah Islamic accounting education, metaphor, secular, capitalist

\section{INTRODUCTION}

The film "Le Grand Voyage" tells about a young man's transcendental process while traveling from France to Mecca to accompany his father on a journey to pilgrimage by car. The trip took 1 week with a distance of $4,898 \mathrm{~km}$. The film is about the clash between a devout man of his faith, Le Pere, and his thoroughly secularized son, Reda, who does not have a clue about the meaning of Islam.

Le Pere, representing people who were educated with the Islamic sultanate system, emerged with a hard-hearted and conservative figure dealing with the rules. He even still speaks Moroccan Arabic to his children during their lifetime in France. Contradictively, Reda is a stubborn, liberal and secular young man who was born and raised in France. Reda's character more or less depicts the current condition of Islamic community which tends to be secularistic.

A stubborn, liberal and secular, Reda is reflexion of students who are taking Islamic accounting courses who are also secular because capitalism is inherent in the reality of accounting. Mulawarman (2012) explained that students prefer anything from the "West"; so in the end it is the Western mindset that they embrace as a form of modernity. The eastern method is inferior to them who are from the East . 
In their journey, the father and the son met a man named Mustapha, a French-speaking Turk who helped them at the border. Le Pere did not show his entusiasm when he met Mustapha who said he wanted to join them on pilgrimage. Le Pere thought Mustapha has bad intentions towardsthem. On the contrary, Reda is very fond of Mustapha who has indulged his curiosity as a liberal and secular teenager.

Islamic accounting students are familiar with the utilitarian value inherent in conventional accounting. Utilitarian does not teach sincere values, it only assumes something is good if it brings benefits or contribution in the end without the process. This is depicted at the time when Reda who welcomed the presence of Mustapha realizedthat Mustapha shows bad intentionby stealing Le Pere's money after taking Reda out for a night of drinking.

Secularism and utilitarianism are inherent in students' life as long as they study conventional accounting and later when they study Islamic accounting they are still attached to these values. Islamic accounting education should liberate an educational process (Kamayanti, 2011). By liberation it is intended to free students from being prisoned in the value of capitalism which is wrapped up by secularism and utilitarianism. The concern is the condition when students are studying Islamic accounting while capitalism is still inherent in their mindset. It gets worse, if the value of capitalism is covered up in the name of Sharia.

Efferin (2015) stated that science and technology, including accounting, were created to shape arrogant people. Why? The answer is because now there has been a complex and multidimensional crisis, where science is often built with submission to dogma, rationality, empiricism, and objectivity to the point that it often makes a secular science with religion. Mulawarman (2008) stated that, the mainstream thought that is developed in accounting is inseparable from the dominance of the secular scientific paradigm which is characterized by three main things, namely self-interest, power, and relativity that are wrapped up with capitalism. Religion or spirituality is considered to have no place in the development of Accounting science.

If the conventional Accounting only deals with struggling on how keep transaction journals and repoting financial statements, which eventually arrive at preparing fundamental information for stakeholders to make a decision, how should learning in accounting sharia be conducted? Islamic accounting education is not sufficient if it only teaches about halal and haram transactions based on the Qur'an and Hadith, the difference between usury and profit sharing, or how to prepare financial statements. Islamic accounting is not just an Accounting science preceded by theword "Sharia".

Accounting cannot only be seen as a tool/practice that is free of value, neither can Islamic accounting. If accounting is only seen as a tool, then the mindset of students will be oriented towards achieving the technical capabilities of Islamic accounting based on technical understanding. Ideally, having a commitment to "sharia" means having a commitment to Islamic values that underlies all life practices. The technical learning process will create students only posses technical understanding of Islamic accounting, such as journaling, sharia financial statements reporting, and the worst will create pragmatic Islamic accounting students. Pragmatism in Islamic accounting education research was carried out by Sari, Triyuwono, and Djamhuri (2016), which explained that technical Islamic accounting learning will produce students who think pragmatically, just knowing about halal and haram, Islamic financial reporting as well as lack of understanding of non-material values in an accounting transaction. If the material presented is still in the capitalist capacity that is defined, then the consumers (in this case are the students) will also be "sharia" human capitalists .

Pragmatic Islamic accountingis also explained by Triyuwono (2012), who stated that accounting that is modified as needed with Islamic values is used for practical needs. In the end, it does not pay attention to the basic sharia values that are deep and the results only creating a pragmatic sharia business world. The main aspect of rahmatan lil'alamin in Islamic accounting has finally become negated because it focuses on technical learning of Islamic accounting. Such learning conducted by educators is done separately between intellectual intelligence, emotional intelligence, and spiritual intelligence, but focuses more on intellectual intelligence. This means that Islamic accounting learning has been reversed, has been "misguided" (Triyuwono, 2010), where intellectual intelligence is considered as the content, while mental 
and spiritual intelligence is considered as the skin. Such education is also what ultimately causes students to think secularly.

Indeed, Islamic accounting presents to deconstruct modern accounting (Triyuwono, 2006). Triyuwono delivered the epistemology of sharia accounting through paired epistemology:

"Islamic accounting seeks to contribute to accounting as a business instrument while supporting the discovery of the nature of self and the purpose of human life. Giving mindset accounting as one of the instruments to "unite with God" (ber Manunggaling kawula Gusti). That is, Islamic accounting is not only the bussiness instrument, but also to unite with God, which is the Almighty to Whom human beings will return (Lillahi Wa Inna illayhi raaji'uun)"

Looking at the epistemology presented by Triyuwono, accounting science and spiritual values should be expected to contribute to sharia business entities and at the same time direct to discover the nature of self and the purpose of life. Islamic Accounting Education is not only about learning the development of sharia business practices, but also as one of the ways and provisions for returning to Allah. The substance of Islamic values is the unity, not the secularity.

Malang Islamic University whose education system is based on the Islamic values of Ahlussunnah Waljamaah, surely teaches various Islamic values in its education process. However, based on the researchers' initial observation, there is still a secularism and utilitarianism which ends in the pragmatism in the mindset of students in Islamic accounting courses taken from conventional accounting courses. Students' understanding about Islamic accounting is still limited to the contract -akad used; and they are still struggling to understand the accounting material in shariah form. In conclusion, the beginning of the researcher turned out that Islamic accounting students do not understand integrated Islamic values that are "fundamental" in Islamic accounting .

Technical learning will lead to banking style learning models (Thomson \& Bebbington, 2004), that can kill critical awareness, even though Islam is a critical religion. Banking-style learning is therefore not in accordance with the spirit of Islam. Understanding the importance of Islamic values and objectives is the first compulsory awareness for teachers and students. It is very alarming when students studying Islamic accounting courses still adopt the inherent values in conventional accounting, because it can shape them to be pragmatic sharia students .

This research will describe the process of "hijrah" sharia accounting students to leave secularism and utilitarianism through the process of education of critical-Islamic awareness by using a film metaphor entitled "Le Grand Voyage". Based on the explanation described above, this paper becomes interesting, because this research is in the field of Islamic accounting education, was conducted at the Islamic University of Malang which is inspired by Islamic values. This research can contribute to add references about awareness in the field of education, especially Islamic accounting education. Rebele \& E. Kent St. Pierre (2015) stated that research published in the top accounting journals has been stagnated. The research published in the accounting journals relates to limited group of topics, uses similar research methods, and is based largely on the same underlying theories. Motivation in this study is education method in this research can be used by Islamic accounting teachers to liberate their students from secularism and utilitarianism. Before teachers liberating the students, they have to liberate themselves first, about the substantive of Islamic accounting.

Besides, the journey of students to attend college is also a "Great Journey", since the mindset of students as agents of hijrah is formed. Hijrah form of Islamic accounting education is a process of emancipation through dialogue without being stuck in the stiffness of textbooks and the numbers in accounting. The research question posed by the researcher is "How does the process of hijrah ${ }^{2}$ of the Islamic accounting students take placeusing the Le Grand Voyage metaphor?.

\footnotetext{
${ }^{1}$ Students as a passive recipients of information must be filled in like a deposit

${ }^{2}$ Hijrah for the Sufis and also the scholars of jurisprudence as an inner strength in setting aside everything other than Allah from the heart. (NU Online, 2018) http://www.nu.or.id/post/read/92567/pengertian-hijrah-dalam-kajian-tasawuf
} 


\section{LITERATURE REVIEW}

Research about Islamic ethics in Accounting education also conducted by Ahmad \& Ahmed (2017). The research shows that incorporating Islamic ethics principles (integrity, sincerity, and righteousness) into Accounting education will be a significant contribution towards generating ethical Accounting students. Sharia foundation of Islamic ethics is good principles, valid, and reliable to enchance Accounting education quality.

Kamla (2015) has conducted a research about critical muslim intellectuals' thought (CMIs'). He illutrated how CMIs' thought based on postcolonial perspectives of cultural hybridity and second modernity can enrich and inform critical accounting research attempts to develop an emancipatory accounting project. This paper demonstrates that CMIs' thought and methodology can contribute to challenging the domination of western/conventional accounting and its claims to objectivity, neutrality and universality. In particular, the paper highlights how CMIs' enlightened approaches to hermeneutics; their emphasis on spirituality, ethics and liberation theology; their radical epistemological and methodological research and education agendas offer outward- looking alternatives to developing accounting thought.

The study about Islamic accounting education has been carried out by Triyuwono (2015b) who deconstructed Islamic accounting education which was allegedly secular, became an education with the main character of Islam, Tawhid. The result stated that the structure of the curriculum, the substance of the subject, the structure of the self and the process of education, the structure of the relationship between the teacher and students and the community need to be integrated into a single form of unity leading to taqwa.

In aother study, Triyuwono (2013) explores the nature of Islamic accounting in terms of its function and objective based on the perspective of khalifatullahfilardh go beyond the worldly life. Islamic accounting functions as an instrument of doa (prayer) and $d z i k r$ (remembering God) for awakening God consciousness. Kamayanti and Rahmanti (2014) also wrote in their article about Islamic Financial Management learning which is often trapped in pragmatism; so it was constructed based on Islamic critical awareness using a dialogical approach. As a result, students can critically practice Islamic Financial Management that have shied away from syariah value and propose alternative solution.

\section{METHODS}

This research is revealed through a story about an exemption which is the empirical result of dialogue obtained from the learning process between researcher and students. Data were collected from recordings and assignments for one semester in the Islamic Financial Accounting class of the Accounting Study Program 2017/2018 academic year at Malang Islamic University. Data taken were in the power point presentation format and tasks.

This research is used to raise awareness of the critical-Islami student using Dialogic technique proposed by Freire as the educational value of love, humility, hope, and confidence (Kamayanti, 2012). However, if Freire stop at the level of love of the world, then in this study, love is transcended towards love for God. The method of analysis in this study takes the philosophical values of the film "Le Grand Voyage" which is metaphorized with the reality of Islamic accounting students.

It is possible to use metaphor as an approach of analysis in an accounting study as explained by Llwellyn (2003):

"... metaphor provides both a "way of thinking" about organizations and a "way of seeing"... metaphor theorizes through linking the unfamiliar to the familiar; it creates meaning and significance through "Picturing" or "image-ing" the world. " 
Llwellyn explained that the use of this approach will form a level of metaphor-based knowledge or what he calls metaphor theorizing, so that it can create meaning and significance through the depiction or imagination of the world. Metaphors in accounting research are also explained by Armenic and Craig (2009): "Metaphors about accounting are important because they affect what people understand about accounting phenomena and concepts."

This research employs metaphor for it can make it easier for readers to understand the explanation of reality and accounting concepts in a more simple way. An example of accounting research that uses metaphors is the one conducted by Kusdewanti et al. (2014), which used "bantengan dan topeng malangan" to describe the reality of Indonesian accounting resistance to the "power" that is currently at war. There are also writings from Triyuwono (2015) who used ball metaphors to conceptualize performance in Arema football clubs. Sari (2016) also made metaphorical research of the triangle hijab as a concept to fight corruption.

This study uses the summary of values implied from the film "Le Grand Voyage" about the migration of a young man metaphorized to see a reality of the hijrah process of sharia accounting students. The process of hijrah that becomes a metaphor is taken from the words or actions of the characters Reda and his father, Le Pere. Based on the explanation, the results of this study are arranged with a narrative style, which by Creswell (2007), has a specific focus and contextual. This narrative style has been carried out by Kamayanti (2012), who uses a dialogical approach to build the (prospective) awareness of accountants through love.

\section{RESULTS}

\section{Secularism in Islamic Accounting}

At the beginning of the journey, Reda who was unwilling to take his father to Mecce for the pilgrimage, drove the car at a high speed. He wants to get to his destination immediately, though he knows it is a very long distance to travel.. His father told him to be careful, but Reda didn't kristen to him. Until one day his father wanted Reda to park his car when he was at customs for a passport check.

"I have to pray," his father said. "Now?", asked Reda with an expression of confusion. "Be patient, we are now in customs," he continued. "Then why?", answered his father. "This is not a place for prayer," answered Reda. His father sighed and looked at Reda while saying, "You believe in God?" Hearing his father's answer, Reda just stayed and finally parked the car.

(Lloyd, 1972) Freire states that in order for the colonized to understand that they are being colonized it is necessary to make an effort to change naive consciousness into critical awareness. That is, even before starting AKS (Islamic Financial Accounting), this awareness effort is a trigger for dialogical learning processes. Like Reda who secularized worship with world activities, Islamic accounting students are actually also being "colonized" by unconscious secularism that has been carried away in accounting.

The lecturer started the course by giving a question to the students regarding the difference of Islamic accounting from traditional accounting to kow the students' initial understansing about accounting. Almost the whole class mentioned money, figures, debit and credit, calculators, financial statements report in answering the quesrion. Based on their initial answer, money, it indicated that accounting students in the 6th semester have been closely tied to the idea that accounting has to do with. Accounting could not be separated from money, since money has taken much of their attention ever since they were in college. The materialistic nature of money has led students to be materialistic as well. After that they continued the answer with things related to money, such as numbers/figures, debit and credit, calculators, financial statements report; all of which were their world in undergoing lectures in accounting.

An understanding of conventional accounting was answered, then I asked thestudents to describe Islamic accounting. Things which came up from their minds were "halal labels, Islamic banks, Al-Qur'an and hadiths, Iqtishad cooperatives (Islamic cooperatives in UNISMA), akad/contracts, mosques (as a place) for zakat management". It can be conluded that students have understood the difference between Islamic and conventional accounting, but only skin deep knowledge. According to the students goods 
without halal labels do meet sharia rules since they associated shariah with halal labels. Islamic Financial Institutions, such as Islamic banks and sharia cooperatives, are now being intensified to be built in Indonesia in a $\mathrm{n}$ attempt to be an Islamic Economic Center. Al-Qur'an and hadith are used as guidelines for Islamic accounting.

The next question I asked them was their purpose of studying in college. They just kept silent a while until some saidFinn to get a diploma and to make our parents happy." But, Faisal, one of the students replied shyly: "For worshipping", he said. Surprisingly, his answer was responded with laughter from others students. One of them even suggested him to go to Islamic boarding school.

I came closer to him and asked him why he said so.. Then he replied to get knowledge and God bless. Alhamdulillah, this is the answer I wanted to hear from the students. It can be concluded that secularism indeed stays in students' mind.

In other dialog with students when discussing conventional accounting subjects, such as Introduction to Accounting I, Introduction to Accounting II, and so on, I asked the students whether they saw the relationship of the subject with religion. Whether God exists in those subjects mentioned. The class was in silence and they looked at each other in confusion. Salma, one of the students, said no for the answer. I tried to provoke their thought by asking them why religion exists. I asked them whether God exists in religion subject. Confidently they said a yes in unison. I then told them that if they thought that God exists in religion subject but not in others it meant that they were secularist. ${ }^{3}$, that they separated the world and the life after No one disagreed.

Islamic accounting education is brought from the conventional secular accounting education system which has forgotten the nature of God's creation of human beings as found in QS 51:56 "And I (Allah) created not the jinn and mankind except that they should worship Me(Alone)".

\section{Capitalism in Islamic Accounting}

"I feel honored to meet such a devout person like you. Today's people only care about money. They don't even think of God any more. Here in Turkey people only work for money whivh in turn oly generates more power", said Mustapha, a person whom they met on their journey to Mecca and wanted to join them.

Reda likes Mustapha as he realizes that Mustapha cacn give him what he can not get from his father, a freedom. Until one day Mustapha takes him out for a night for drinking and ended by stealing hi father's money. The incident does not even change Reda's character who still keep being selfish and materialistic.. Reda is angry when his father just gives the money for them to go home to a beggar woman. He can not understand the reason undeerslying his father's deed. They then in involve in a serious squabble.

The story illustrates the circle of capitalism. Wealth only belongs to those who have a lot of money and power. Nowonder if such people treat money as their god (in small g) and money is the goal of life of the capitalist.

Capitalism according to Triyuwono (2006), is not value-free, because during the process of its creation it involves human beings who have personality and are full of interests. The main values inherent in modern accounting are egoistic and materialistic values that are embedded in utilitarian values. So this is where Islamic accounting is present to deconstruct modern accounting. Islamic accounting as a business instrument also supports the discovery of the nature of self and the purpose of human life.

At the beginning of the Islamic accounting lesson, there were two students who could not take courses, because they were late. The following week they met me to ask me do write their names on the attendance list by telling me excuses for their absence.

\footnotetext{
${ }^{3}$ Secular is separate material aspects as one of human needs with substance as spiritual beings. Or can be split between the world and the hereafter, where nature is actually something that is a unity. For example, separating worldly knowledge from the science of religion, separating material things from the spiritual. the concept of Tawheed, should all these things are inseparable (Triyuwono, 2015b)
} 
Sardi, one of the late coming student begged on me not to cross his name on the attendance since he had been absent before and the absent would affect his grade. It turned out to me that all his efforts was to save his grade.. The similar thing happens to Mustapha, one of the character in Le Grand Voyage, who lies to Reda and his father and deceits them as well for the sake of money.

In his book, Triyuwono (2012) states that if accounting is formed by the environment in a capitalist environment, then the information conveyed also contains capitalist values. Then the actions and decisions taken also contain capitalist values, so the reality created by accounting is also capitalist reality.

"You are accounting students, aren't you?". After explaining the material on the slide, I asked students. "Yes ma'am," they answered. "If so, you are the reality of accounting right?" "Yes ma'am," they replied again. I just looked at them, "so, we're capitalist?" said one of the students, and the other was silent. "I didn't say it, but your friend did" I replied. "What kind of capitalism, ma'am?" Asked Giman. "We're not a company," he continued. "Is capitalism only takes place in the company? No. Capitalism also exists in our everyday lives. Okay, are you capitalists or not. Ask your hearts, huh?"

I gave a break to students to get ready. "The most important interest of the company is profit, money What is the main interest of students?" A moment of silence, they thought, then there were some students who answered,"A grade, Ma'am." with hesitation. "Yes, your interest or your ego is value. That is the first characteristic. The second is materialistic, If the company's materialistic character is profit oriented, Wat about you? Is it the GPA oriented?" They nodded. "The last one is utilitarian. Utilitarian is when something is considered correct it if it brings utilities (material benefit) for himself, and without seeing how the process takes place what is important is to get A grade. Am I right?" They just stared at me. "Why do you just keep quiet?" I asked them. "I was thinking ma'am, why do I feel like that?" Sarmi answered with a smile. "Yes ma'am, I'm also asking my heart." Surya answered. "So what do you feel?" I asked them again. Sarmi answered cautiously, "I am capitalist ma'am."

Capitalistic accounting will form a capitalistic network of power. The net power is profit. You could say that the profit becomes a worship or pseudo god for the capitalists. Making pseudo orientation of human life orientation, and turning to the power of God. This reality makes people forget the creed "Laa ilaa ha illa Allah" that there is no other God than Allah.

\section{DISCUSSION}

\section{Liberating Process}

"There is something I want to ask" said Reda, "Why don't you take a flight to Mecca? That's much easier." The father replied, "When sea water rises into the sky, it will lose its saltiness to become pure again."

"I mean it", said Reda to confirm his father's answer. "Sea water evaporates as it rises to the clouds, and when sea water evaporates, it will become fresh water. That's the reason why it's better to take a pilgrimage on foot than to ride a horse, and it's better to ride a horse than to drive a car, and it's better to drive a car than to take a boat, and it's better to take a boat than to take an airplane."

Islamic accounting is created technically and philosophically. Technically, Islamic accounting exists because of the growing development of sharia business entities in Indonesia. Philosophically, Islamic accounting was created to free the net of power of all capitalism (Triyuwono, 2012), which was obtained from conventional accounting that was not value-free. Before stepping on Islamic accounting material, students are first made aware of this capitalist reality.

\section{This A Great Journey, Not For Travelling}

"Why don't we stop in Milan? Maybe I will never see it." Asked Reda. "What are you going to do in Milan?" Replied his father. "I don't know ... taking photos, seeing the sights, going around the city," said Reda. "Do you think we are tourists? Stop in every city we go through?" 
Reda's father has a great mission to Mecca, which is to perform the pilgrimage. So why doesn't he take the plane to get there faster? Because he wants to enjoy every second of his journey, to make it holy and clean again when he arrives at the Baitullah. Reda, on the contrary, his only purpose is to accompany his father.

The goals of college students are also varied. Their goal is to conquer the world, to get prosperity, or in other words to become rich. This goal makes them forget the purpose of human creation by God, namely to worship Him. Worship in a narrow sense is like doing shalah, zakat, fasting, hajj, and so forth. The goal of worshipping is to achieve prosperity in the afterlife. "Is it distinguished like that for the purpose of the world and the hereafter?" I asked the student. "Yes" everyone answered at the same time.

I told them that it was really a shame if they thought that way; that worshipping were only do prayer, fasting, give charity, and the like. For the moment the class was in silence and I let them to think. I then asked them to calculate the 24-hour time they had in a day. "OK, class as accounting students you must be good at working with numbers. You have 24 hours a day, and you have to pray five times a day, don't you? How much time do you spend for each prayer?" "5 minutes mom," Ayu replied. "Only 5 minutes? Let's say 10 minutes. 10 minutes multiplied by 5 is closer to 1 hour. That is the time you spend to pray in a day including all the sunnah prayers and dhikr. What about Qur'an recitation? 3 hours?" "Hahahahaha, it's too long Ma'am. One hour is more than enough, Ma'am" Sarman answered. "Then how much? 2 hours? Ehm, let's make it 2 hours. So, how many hours doyou spend your time for worshipping? 3 hours, right? Then added with the night prayer (tahajjud prayer) for about an hour".

"How much is the total? 4 hours, isn't it? In 24 hours you spend 4 hours for worshipping, for the purpose of the afterlife. And the rest is 20 hours used for worldly affairs. Oh, I see? Whereas the afterlife is much longer than the world, it is the eternal life. Astaghfirullah. How long do we live in this world, 65 years? 70 years?"

"Nobody knows, Ma'am, it could be just an hour." Ayu replied. "Well, how longdid the Prophet Muhammad live in this world? 63. If we live longer than the Prophet Muhammad did, it means we get a life bonus from Allah, so that we can do worshipping will be longer." I replied.

"Allahmdulillah ... what a pity it is; 20 hours for the worldly affairs compared to 4 hours for the afterlife. What do you think?" I waited for the students' response. "What can we do, Ma'am?" asked Ayu

"We must redesign our life's goal and focus all the efforts for worshipping, Ma'am." Siti answered. "Yes, that's right, set the afterlife as our gol in life and all we do must lead to the afterlife. Innamal a'malu bin-niyat, "Indeed all actions are based on the intention". Intend your study for worship, work for worship. So it is no longer secular, wordly affairs are mingled with the afterlife affairs.. The world is a place to find provisions for the afterlife, so don't jus spend 4 hours for the hereafter. The world is not a place for traveling, just to have fun, nor a place to get wealth.

All students agreed that life should lead to the afterlife happiness.. The hijrah process does not stop here. As discussed earlier, secularism is also found in other subjects such as religion and conventional accounting courses.

"Well, if in Islamic accounting we can discuss about Allah, about blessings, about worship, why can't we do that in conventional accounting courses? Have you ever discussed the bless of profit in conventional accounting courses?" Some students laughed, and some answered, "absolutely no, ma'am."

"Yes, I can not agree anymore with you that there is no discussion about the bless of profit except a discussion about profit maximization. You have learnt how to maximize profit. How could it happen? Do you think there's no place for God in conventional accounting? Do you think that it happens because it has to? When you study Islamic accounting, Islamic economics, religion you are aware that God is there. What do you think about God when you study Introduction to Accounting 1 and 2? Do you think that God is also there? " The student just kept silent.

"Who created the knowledge?" I asked. "Allah." Replied the student. "Well, accounting is also part of science, who created accounting science?" I asked. "Allah." Replied the student. "Then why, in conventional accounting, IA-1 and IA-2 it feels strange or even taboo when discussing God, and bless in the profit?" 
"The lecturer never discusses about Allah, Ma'am," said Budi. "There is one lecturer who is associated with religion, Mr. Anwar. If he teach early, it was connected with Islam," continued Ayu. "Alhamdulillah. So, what do we have to change so as not to be secular in education anymore?" I tried to provoke the students. "The education has to change," said Budi. Cheers and applause filled the room. I smiled happily and gave two thumbs up to Budi.

The current education system that secularizes religion from science makes students also secular. Science, or in this case conventional accounting relies on rationalism (true by definition) and empiricism (observable), which is different from religious science which is not all rationalized. Changes in the education system as conveyed by Al-Faruqi which is adapted by Suyuthi (2012), that the biggest task of a Muslim is "solving education problems". So, he declared "there will be no hope of a true revival of the Muslims unless the education system is changed and mistakes are corrected ... dualism in the world of Muslim education, dualism in the form of Islamic and secular education system must be stopped and eliminated. Both systems must be united and integrated."

\section{Critical-Islamic Thinking}

"Why is going to Mecca so important? Why is Mecca so special? "Reda asked his father.

"We've come this far and now you're just interested in asking? Mecca is the main holy city for Muslims. People come from all over the world. It is the legacy of Prophet Ibrahim AS." His father approached Reda, and continued "Hajj is important. It is the fifth pillar of Islam. All capable Muslims must carry it out before they die to purify their souls. We all will die later. We are only guests in this world. The only thing I fear is to die before carrying out Hajj. And without you, I will never succeed. May Allah bless you. I learned a lot from this trip."

"So do I." Reda replied while smiling.

The question raised by Reda to his father began to raise his awareness, or his interest in Islam. Citing Freire's statement through the writings of Kamayanti and Rahmanti (2014), that in order for the colonized to understand that they are being colonized, an effort must be made to change naive consciousness into critical awareness. In this case the colonized are students in the reality of their accounting knowledge, who unconsciously have imprisoned the mindset of students. It is through this critical Islamic thinking that will be used to free the Islamic consciousness of students over capitalism that encompasses its reality, which is enveloped in a materialistic, selfish, and utilitarian way.

The above discussion has proven that Islamic accounting students have realized the existence of materialistic, selfish and utilitarian values in themselves. To free them, I used videos and "suburban cases", and asked them to analyze the accounting and the values carried in it.

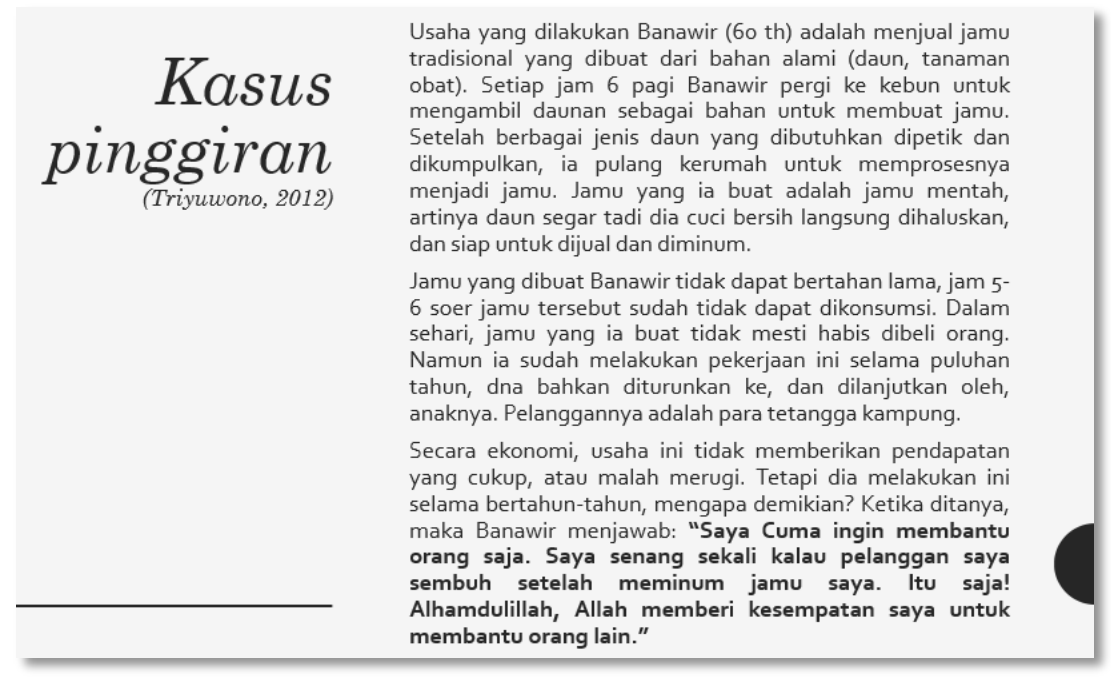

Figure 1. Suburban Cas 
Based on the suburban case above, students were asked question regarding what Banawir got from selling herbs. Students are given 5 minutes to read and answer.

"Do you notice the accounting practice in what Mr Banawir does?" I asked the students. They try to digest, and answer. Some said "yes", and some said "no". Students who answered "yes" were based on the fact that Mr Banawir is selling herbs. That is an accounting practice.."

That the man selling herbal medicine is an accounting practice. How does he get the capital? From nature; it is provided by the nature. Then the herbs is sold. That's accounting practice." After talking about accounting in the suburban case, I asked my students to mention what profit or obtained by Mr. Banawir, Alhamdulillah, that all their answers were what I wanted from them: blessings, rewards, helping others, feeling happy, grateful".

"Is that the only profit that Mr. Banawir got? Are you sure you?" I asked the student. They thought hard to answer. "You forget one important thing, but I'm glad if you forgot this important thing. What is that?" They were still confused looking for the answer. "You forget mentioning Money as one of the profits he got, Alhamdulillah." After I said that the whole class was thundering, aware of their shortcomings, about money, which usually always sticks in their minds, but this time they can forget about it. "Wow, you successfully made us forget about money. Hurray we were not capitalist." Budi shouted excitedly at me, and was followed by his friends.

After I gave the case, then I showed them a video. The video tells about a man who, although he is not a rich person, is very concerned about his surroundings. He often gives money to needy children until they could go to school, help grandmothers push carts and sell, distribute food to a starving dog, and water flowers that almost died on the side of the road. He does not want to be rich, but he is "rich" with the love he gives to the surrounding environment. The student's job is to observe the main character and what values are captured from the video.

Today's meeting was closed with a task next week to look for accounting practice and its value in students' daily life. Here are some of the results:

Story telling \#1 was from Sonia:

On October, 3th I was returning home from college when I saw a cat was in pain near my boarding house., I came closer to the cat, and I saw a bleeding wound in its body. I was panicked and knew nothing about what I should do. I was so sorry seeing the weak and helpless cat. I immediately called my friend to accompany me to take the cat to the veterinarian. Arriving at the House of Pet the doctor immediately handled it and the doctor said this cat had to be operated because the nipples were scratched and there was a maggot on the nipples. I asked the vet to do his best to save the cat. I spent IDR 810,000 of mysocial gathering money to take care of the cat. Actually, I wanted to use the money to buy daily needs, but by being able to help the cat I was happy.

Value added: I felt so happy because I could see that the cat was healed. That is the added value that I got. I felt satisfied. 
Story telling \#2 by Hadi (directly presented before the class):

"Last Saturday I was on my way to buy a jacket, when I saw an old female beggar sleeping on a used rice sack. " I felt sorry seeing that beggar as she reminded of my grandmother at home. I could not imagine if it happened to my grandma. I then decided to give my money to her. Not though,, but hopefully it could be a help. "

"Where does it take placeis that?" I asked.

"Near the city station, Ma'am. Well, after that I went to a shop. I saw a jacket that I liked. However, when I looked at the price tag, my money was not enough, to buy that jacket, because I have given some of it to the beggar. So I decided to go back to the boarding house to take some more money. On my way home I stopped by to another shop to look at some jackets there. Lucky me! There was a jacket that was exactly the same as the one I wanted, and this jacket was also at a discounted price, Ma'am. Finally I bought it and now I am wearing it”. I saw a happy look on his face.

"Cieeee," his friends said, and followed by hand claps from them.

"Okay, what did you get from your story?" I asked Hadi

"I'm happy, Mom, because I can help the old female beggar. I imagine what if she were my grandmother or my mother. So without consideration, I immediately gave my money to her. "

"Alhamdulillah. Do you still get the change? "I asked

"Hehehe, yes ma'am. There's still a change. "

"Well, it means that yesterdayyou got a reward from Allah, InsyaAllah and got a discounted jacket " I concluded, and agreed with Hadi.

Based on the two stories about above, there are several values that can be seen. First, the material value, namely the expenditure that Sonia spent to treat the cat, and that Hadi spent to be given to an old beggar and to buy a jacket. Second, the value of altruism shown by the two students. They are more concerned with the interests of other creatures rather than their own interests. Third, the value of love. Fourth, the spiritual value of inner satisfaction by giving help treat sick cats and an lob woman. For Hadi, he was also because he could get a jacket at a cheaper price.

\section{CONCLUSION}

The dialogical approach raises a lot of student awareness. Divine or spiritual awareness arises when discussing the presence of God in conventional accounting courses and religious science courses. Awareness of emotional values and spiritual values has also been produced. That accounting is not only about how to record journals, financial statements reporting and provide them as information for stakeholders, but more deeply, in every accounting reality there is a value that follows it, not only material value, but also non-material. Emotional values such as love for fellow creatures of God, the value of altruism that leaves self, and the spiritual value of gratitude and inner satisfaction have given grace to all nature. Even so, the limitations of this research lie in the inability to capture the results of research which are the results of the dedication of students are carried on permanently by students and so on. It cannot be sure that this glorification will be permanent in the mindset of students, but it can be sure that the process of this dedication is real. This kind of process can be carried out on all types of courses, not limited to Sharia Accounting only. Dialogic approach in learning will be very good if it is done on conventional Accounting courses, as a preventive step against secularism and capitalism. 


\section{REFERENCES}

Ahmad, N. L., \& Ahmed, H. (2017). The Acceptability and Impact of Sharia Foundation of Islamic Ethics in Accounting Education. International Journal of Academic Research in Business and Social Sciences, 7(2), 494-506.

Armenic, J., \& Craig, R. (2009). Understanding Accounting through Conceptual Metaphor: Accounting is an Instrument?". Critical Perspectives on Accounting, 20, 875-883.

Creswell, J. (2007). Qualitative Inquiry \& Research Design: Chosing Among Five Approaches. California: Sage Publication.

Efferin, S. (2015). Akuntansi, Sspiritualitas dan Kearifan Lokal: Beberapa Agenda Penelitian Kritis. Jurnal Akuntansi Multiparadigma, 6(3), 341-511.

Kamayanti, A. (2011). Liberating Accounting Education Through Beauty and Beyond. Universitas Brawijaya.

Kamayanti, A. (2012). Cinta: Tindakan Berkesadaran Akuntan (Pendekatan Dialogis Dalam Pendidikan Akuntansi). Simposium Nasional Akuntansi XV Banjarmasin 2012, (April), 1-30.

Kamayanti, A., \& Rahmanti, V. N. (2014). Melucuti "Kerudung" Manajemen Keuangan Syariah: Pembelajjaran Berbasis Pendekatan Kritis Islami, 507-524.

Kamla, R. (2015). Critical Muslim intellectuals' thought: Possible contributions to the development of emancipatory accounting thought. Critical Perspectives on Accounting, 1-11. http://doi.org/10.1016/j.cpa.2015.01.014

Kusdewanti, A. I., Setiawan, A. R., Kamayanti, A., \& Mulawarman, A. D. (2014). Akuntansi Bantengan: Perlawanan Akuntansi Indonesia melalui Metafora Bantengan dan Topeng Malangan. Jurnal Akuntansi Keuangan Indonesia, 5, 149-169.

Lloyd, A. S. (1972). Freire, Conscientization, and Adult Education. Adult Education Quarterly, XXIII(1), $3-20$.

Llwellyn, S. (2003). What Count as "Theory" in Qualitative Management and Accounting Research: Introducing Five Levels of Theorizing. Accounting, Auditing \& Accountability Journal, 16(4), 662708.

Mulawarman, A. D. (2008). Penyucian Pendidikan Akuntansi Episode Dua: Hyper View of Learning dan Implementasinya. Tema, 9(1), 53-66.

Mulawarman, A. D. (2012). Pendidikan Akuntansi Indonesia: Pro Neoliberal atau Pancasila? Konferensi Nasional Pendidikan Akuntansi Indonesia, (October), 1-18.

Rebele, J. E., \& E. Kent St. Pierre. (2015). Stagnation in accounting education research. Journal of Accounting Education, 33(2), 128-137.

Sari, A. F. K. (2016). Hijab Segitiga Akuntan untuk Melawan Korupsi. Jurnal Ekonomi Modernisasi, (1), 23-34.

Sari, A. F. K., Triyuwono, I., \& Djamhuri, A. (2016). Pragmatic on Islamic Accounting Education, (11), $1033-1037$.

Suyuthi, A. (2012). Islamisasi Ilmu Pengetahuan: Sebuah Tawaran. Al-Hikmah, 2(1), 78-88. 
Thomson, I., \& Bebbington, J. (2004). It doesn't matter what you teach? Critical Perspectives on Accounting, 15(4-5), 609-628.

Triyuwono, I. (2006). Akuntansi Syari'ah: Menuju Puncak Kesadaran Ketuhanan Manunggaling Kawulo Gusti. Pidato Pengukuhan Guru Besar.

Triyuwono, I. (2010). Mata Ketiga Sè Laèn, Sang Pembebas Sistem Pendidikan Tinggi.pdf. Jurnal Akuntanssi Multiparadigma, 1(1), 1-23.

Triyuwono, I. (2012). Akuntansi Syariah Perspektif, Metodologi dan Teori (ketiga). Jakarta: Rajagrafindo Persada.

Triyuwono, I. (2013). So, What is Shariah Accounting. Imanensi, Vol. 1(1), 42-50.

Triyuwono, I. (2015a). Akuntansi Malangan: Salam Satu Jiwa dan Konsep Kinerja Klub Sepak Bola. Jurnal Akuntansi Multiparadigma, 6(2), 290-303.

Triyuwono, I. (2015b). Filosofi Tauhid: Mendekonstruksi Pendidikan Akuntansi Syariah yang Sekuler. Workshop Nasional Kurikulum Akuntansi Syariah, 1-20. 